\title{
Thomas Hobbes és a természeti állapot dilemmái I.
}

\author{
A totális háború axiomatikus volta
}

\author{
NAGY LEVENTE ${ }^{1}$
}

\begin{abstract}
ABSZTRAKT
A tanulmány a kora modern kor egyik legmeghatározóbb politikai filozófus - Thomas Hobbes fó müvére, a Leviatánra való reflexió. Ebből nem következik automatikusan, hogy jelen írás a mú egészének elemzésére, a szerző morálfilozófiájának vagy államelméletének átfogó bemutatására, netán Hobbes, a politikai gondolkodásra gyakorolt hatásának kifejtésére vállalkozik. A cél ennél szerényebb, a vizsgált terület szúkebb: a Hobbes-i hatalomelmélet dilemmákkal telített premiszszájának, a természeti állapot néhány szempontjának elsősorban analitikus módszerrel történó elemzése. A kezdeti helyzetre vonatkozó, ambivalens kérdések annak reményében fogalmazódnak meg, hogy e kérdések több oldalról történö megvilágításával rámutassunk a téma komplexitására, illetve hogy a tanulmányban rögzítettek továbbgondolásra serkentsék az olvasót.

Jelen írás Hobbes általános filozófiájának bemutatásával és a Leviatán logikai rekonstrukciójával indul. Ezt követôen a természeti állapottal kapcsolatos két aspektus rövid elemzésére kerül sor: elöször az eredeti helyzet és a Teremtés története közötti analógia felvetése a cél, a feltételezett szerzôi szándék szemmel tartásával. Másodszor, a kezdeti helyzet esetleges fejleményei alapján a totális háborúba torkollás axiomatikusságának vizsgálata kerül a középpontba. Az elemzésból kiderül, hogy a válaszadás egyik kérdésre sem annyira egyértelmü.
\end{abstract}

KULCSSZAVAK: emberi természet, természeti állapot, mindenki mindenki elleni háborúja, civil társadalom

\section{ABSTRACT}

\section{Thomas Hobbes and the dilemmas of the natural state} First chapter - The axiomatic nature of total war

The purpose of this paper is to reflect on some the ideas of Thomas Hobbes, one of the founders of modern political philosophy, best known for his masterpiece, Leviathan. The aim of this essay is not to provide a full scale analysis of Hobbes' main work, nor to present his moral or political philosophy, nor to reflect on the significance of his impact on later political thinkers. The aim is more modest, and the theme under scrutiny is more narrow: the paper is devoted to a critical analysis of the main premise (state of the nature) of Hobbes' theory of power, including the ambivalent character of the state of nature, as well as the logical dilemmas that arise during the analysis.

\footnotetext{
${ }^{1}$ Debreceni Egyetem, Politikatudományi és Szociológiai Intézet, Politikatudományi Tanszék.
} 


\section{TANULMÁNY}

After a general presentation of Hobbes's philosophy and of the logical construction of his work, I will tend to focus on two aspects of the state of nature: firstly, I will analyse the assumed analogy between the state of nature and the Book of Genesis; secondly, I will examine whether the "war of all against all” is an axiomatic outcome of the "primitive” state. It turns out, that the answers for these questions are not so unanbiguous.

KEYWORDS: human nature, natural state, everyone's war against everyone, civil society

\section{Bevezető}

E tanulmány nem Hobbes államelméletének teljes bemutatása, nem morálfilozófiájának kifejtése, se nem egy átfogó eszmetörténeti tanulmány vagy a Leviatán politikai gondolkodástörténetben játszott szerepének bemutatása, és nem a társadalmi szerződés aktusának tüzetes elemzése. Ennél szerényebb - de távolról sem könnyű - célt tűzött maga elé: Hobbes általános filozófiájának dióhéjba foglalását és államelméletének logikai rekonstrukcióját követően ez az írás - a teljességre való törekvés igénye nélkül - a Hobbes-i hatalomelmélet alapjául szolgáló kiinduló helyzet, a természeti állapot néhány problémájára, ambivalens kérdésére irányuló reflexió. E kezdeti állapot értelmezése során „vegyes” módszert alkalmazok, ugyanis hol a kontextuális megközelítést tartom szem előtt, hol a feltételezett szerzői szándék felvetését helyezem előtérbe, máshol pedig a Hobbes művének szoros szövegolvasatát feltételező analitikus módszerre támaszkodva kísérelek meg körüljárni két kérdést: ${ }^{2}$ egyáltalán lehet-e (érdemes-e) a Hobbes-i természeti állapot és a Teremtés könyve közötti analógiáról beszélni a feltételezett szerzői szándék alapján, illetve mennyire mondható axiomatikusnak a totális háború bekövetkezte?

\section{Hobbes általános filozófiája}

Hobbes visszautasította az előző századokban uralkodó, de korának is még divatos bölcseleti módszerét (skolasztika), amely elismerte, hogy a tudományos vizsgálatnak van némi - korlátok közötti - szerepe, de a világ végső megismeréséhez csak a hit által lehet eljutni. Transzcendenciától mentes filozófiai rendszer kiépítésével próbálkozott, és figyelmét inkább az új tudományok kötötték le: a matematikára, a természettudományok új eredményeire, a vérkeringés felfedezésére ${ }^{3}$ támaszkodva

\footnotetext{
${ }^{2}$ A Hobbes által ábrázolt kezdeti helyzet kapcsán olyan további szempontok kerülhetnek reflektorfénybe, mint: a természeti állapot idődimenzió-mentessége/időtartammal rendelkezése; a természeti állapot emberének „természetes” volta; a kezdeti helyzet emberei közötti viszonyok; a természeti állapotok tipológiája. E szempontok - amelyek még inkább rávilágíthatnak az eredeti helyzet bonyolult voltára egy következő tanulmányban kerülnek majd górcső alá.

${ }^{3}$ William Harvey (1578-1657) az 1628-ban megjelent múvében, az Exercitato Anatomica de Motu Cordis et Sanguinis-ban fejtette ki a vérkeringéssel kapcsolatos felfedezéseit.
} 


\section{TANULMÁNY}

közelítette meg a filozófiát, és minden létezőt az egyetemes mozgás eszméje útján próbált magyarázni. Így jutott arra a következtetésre, hogy a filozófia tárgya az anyag vagy test, ami lehet természetes, középpontjában az emberrel (human body), illetve mesterséges (body politics), ez utóbbi lévén az állam.

A mozgás középpontba helyezésével Hobbes a folyamatok mechanikai magyarázatára törekedett, érthető ezért, hogy filozófiája miért annyira mechanisztikus (fizikai mozgáson alapuló). A filozófus szerint a mozgás folytán az elemi részecskék mechanikus ingert gyakorolnak egymásra, a mozgás így aktív erővé válik, megteremtve a dolgok ok-okozati összefüggéseit. A tárgyakból kiinduló ingerek, vélte Hobbes, váltják ki végeredményben az érzelmeket, az akarat megnyilvánulásait, vagyis az emberi motivációt, amelyet le lehet bontani elemi részeire. ${ }^{4}$

Az emberi érzelmek és a mozgás összekapcsolását úgy oldotta meg Hobbes, hogy a mozgást egyenesen a vonzás (tetszés, szeretet, kényelem, értékes) vagy taszítás (nemtetszés, gyülölet, veszély, rossz) előidézőjeként és fenntartójaként értelmezte. Ilyen formán a vonzásra vezethető vissza az önfenntartás ösztöne, a taszításra pedig a halálfélelem. Hobbes még a boldogság fogalmát is mechanisztikus megközelítéssel magyarázta, hiszen szerinte az nem más, mint „a vágy állandó elörehaladása az egyik tárgytól a másikig, ahol az előbbi elérése csupán a másik eléréshez vezető út" (Hobbes 2001: 131). A mozgás tehát az önfenntartás alapértéke, az élet fenntartója, a mozdulatlanság viszont a halál sajátja.

Erre a mechanisztikus alapra építette Hobbes az emberi természet (szükségletek, szenvedélyek, képességek, erők stb.) átfogó pszichológiai rendszerét, és az sem a véletlen eredménye, hogy az emberi természet kibontásával indul klasszikus műve, hiszen filozófiájának egyik lényegi pontja a gondolatmenetek „kezdeti” okainak előtérbe helyezése. Ennek magyarázata, hogy Hobbes teljes meggyőződéssel hirdette, hogy államelméletének megértéséhez, az ok-okozati összefüggéseken belül az okra, vagyis az emberi természetre, és az ebből adódó természeti állapotra kell mindenekelőtt figyelni, mert ennek megfelelő tanulmányozásával lehet csak megérteni a politikai állapot mibenlétét, az államalapítás lényegét, az abszolutisztikus hatalom szükséges voltát. Ezt olyannyira hitte Hobbes, hogy az okok nem ismeretét egyenesen a tudomány hiányával azonosította (Hobbes 2001: 135-36,138). Idevágó gondolatainak szem előtt tartásával a Leviatán lényege - egy kis leegyszerűsítéssel egyetlen mondatba tömöríthető: a korlátlan hatalommal bíró szuverén megjelenése az emberi természet, illetve a politikamentes állapotra jellemző antropológiai körülmények tarthatatlanságának szükségszerü következménye.

${ }^{4}$ Ez a megközelítés eléggé azt a benyomást kelti, mintha az ember egy gépezet lenne, amelynek alkatrészeit vizsgálva megértenénk magát az embert, a maga komplex lelki és szellemi világával. Nem véletlen, hogy Hobbes nagy támadási felületet szolgáltatott „túlzottan mechanisztikus” filozófiája ellen. 


\section{TANULMÁNY}

Korábbi műveiben ${ }^{5}$ már kifejtett gondolatainak mesteri összegzését nyújtja a $L e$ viatán, amelyen végigvonul Hobbes - fentebb is említett - tudományos módszere: bármely rendszer megértése érdekében az egészet elemeire kell bontani (dedukció), azért, hogy láthatóvá és érthetővé váljanak az elemi részek működési elvei a közöttük fennálló összefüggések, valamint egységbe szerveződésük oka (indukció). Egy kis leegyszerűsítéssel, két, egymáshoz kapcsolódó ok-okozati összefüggés alkotja Hobbes hatalomelméletének eszmei tengelyét: az emberi természet (ok) önpusztító állapotot eredményez (okozat), amely a maga módján (ok) a politikai társadalom létrehozásához (okozat) vezet. A dedukció-indukció sajátos alkalmazása ez, ${ }^{6}$ és mint kiderül, ezek nem egymással szembeállított, hanem sokkal inkább két, egymást feltételező és egymás számára nélkülözhetetlen módszerként tételeződtek Hobbes számára.

A szerző meg volt győződve arról, hogy módszerének alkalmazásával (akár a mértan, amelynek lépésről lépésre követhető szigorú logikája pontos eredményeket szolgáltat, és megalapozott bizonyítást nyújt) olyan kiszámítható és cáfolhatatlan eredményeket kaphat, amelyek még a legkételkedőbbeket is meggyőzhetik majd. ${ }^{7}$ Nem túlzás azonban azt állítani, hogy művével Hobbes nem a történelmi „igazság” feltárását tűzte célul, ugyanis nem az állam előtti állapot valós és pontos leírására, de nem is a tiszta természeti állapotról a civil társadalomra való áttérés folyamatának „hiteles” bemutatására törekedett. Filozófiájának erényét annak meggyőző erejében kell elsősorban keresnünk, abban, hogy a tudományos igénnyel megírt morál- és politikai filozófiája részleteiben vizsgálja meg a tökéletlen, belső háborúktól önmagát felemésztő államot, annak érdekében és reményében, hogy logikai érvsorozatával megoldást nyújtson a fennálló problémákra. Annak ellenére, hogy művének logikája átgondolt és erőteljes, mégis óvatosnak kell lennünk ennek megítélésében, ugyanis Hobbes érvsorozatai gyakran metaforákkal végződnek (Ludassy 2007).

\section{A Leviatán logikai rekonstrukciója}

Mivel is próbálkozott Hobbes? Egy „örökzöld” kérdésre kísérelte meg a válaszadást, amely a görög antikvitás óta foglalkoztatja az európai kultúrkört: Milyen politikai

${ }^{5}$ The Elements of Law (1640), De Cive (1642). Ezek továbbgondolásának és továbbfinomításának eredménye a Leviatán (1651).

${ }^{6}$ Ez az általánosítás kézzelfoghatóbbá válik, ha arra gondolunk, hogy Hobbes tulajdonképpen a történelmi valóság „általános” helyzetéből, az angol polgári forradalomból mint okozatból indult ki és haladt az okok (a közhatalomtól mentes természeti állapot) felé, majd a kezdeti tarthatatlan állapot okainak (emberi természet) kellő megismerésével és megértésével Hobbes összerakta az okozatot, az ember által létrehozott szuverén hatalmat.

${ }^{7}$ Hobbes idevágó „magabiztossága” ellenére érdekes kérdésként tételeződhet, hogy ha lépésről lépésre haladó mechanisztikus módszere mértani pontosságú eredményekhez vezet, akkor vajon miért kellett több alaklommal is szóképeket, metaforikus képábrázolásokat használnia logikai következtetéseinek végső kifejtéséhez. 


\section{TANULMÁNY}

berendezkedés lehet a legalkalmasabb a „jó élet” megvalósításához? Kora történelmi tapasztalataiból kiindulva, a Machiavelli által egyedül életképesnek tartott központosított állam, illetve a Bodin által is alátámasztott, általános törvényszerűségekre alapozott abszolút monarchia szükségességének gondolatait figyelembe véve, Hobbes tudományos szintre emelte államelméletét, amely nem kevesebbet állít, mint hogy egységes és oszthatatlan politikai entitásra, és ezen belül abszolutisztikus hatalomra van szükség a rend és béke létrehozása és fenntartása érdekében, illetve hogy a szuverén hatalomgyakorlás megalapozott legitimitását nem az Istentől vagy a hódítás jogából származtató, hanem elsősorban az emberi szerződés útján létrehozott államban kell keresni.

Dióhéjba foglalva, a politikai közösség, és ezzel a szuverén hatalom létrejöttét Hobbes egy újkori mítoszhoz ${ }^{8}$ (szerződéskötés mítoszához) kötötte, egy olyan fiktív aktushoz, amelynek kiindulópontja a természetes körülmények között élő, szenvedélyeitől és indulataitól vezérelt ember, a maga természetes, civilizációtól lecsupaszított mivoltában. ${ }^{9}$ Nem alaptalan a kérdésfeltevés: Miért is gondolta Hobbes, hogy vissza kell mennie a hatalom eredetének vizsgálatához? Úgy tűnik, azért, mert tudta, hogy az eredet tisztázása egyben a „jelen” dolgainak jogosságára is fényt deríthet, hiszen a korszellemnek megfelelően a „kezdet” mint kronológiai elsőbbség szakrális jelleggel bírt, és a dolgok helyes rendjének a „jelenben” való megértéséhez vissza kell menni az eredethez, a kezdeti pillanathoz, aminek keresztényi értelemben nemcsak szakrális, hanem primordiális volta is van.

Mint tudjuk, Hobbes nem állt, és nem is állhatott meg a Teremtés történeténél annak ellenére, hogy e történet Hobbes idejében igencsak hiteles forrásnak számított még -, annál is inkább, mivel erre az átmenetinek minősülő századra nemcsak a kezdet tökéletességében vetett keresztényi hit, és ezzel a múlt szentesítése volt jellemző, hanem egyre inkább előtérbe kezdett kerülni a kiszámítható jövőbe vetett hit kérdése is. Ez, a maga nemében - Hobbes esetében mindenképp - egyfajta súlyeltolódást jelentett a hatalom szekuláris felfogása irányába, megfogalmazva azt a kihívó kérdést, hogy az uralkodó vajon közvetlenül Istentől kapja hatalmát, vagy inkább az emberektől származtatható az.

Visszacsatolva Hobbes gondolataihoz, a legalapvetőbb ösztöne (élete megóvása) által vezérelt ember önmaga fenntartására törekszik, de az emberek viselkedését kordában tartó általános jog hiányában mindenki maga dönti el ebben a sajátos hely-

\footnotetext{
${ }^{8}$ Természetesen ez a mítoszként kezelt fiktív aktus nem tévesztendő össze az eredetmítoszokkal (mint például a görög mitológiák, vagy Róma megalapításának mítosza). Ennek kapcsán lásd - Hannah Arendt gondolataira alapozva - Balogh 2010: 101.

${ }^{9}$ Két megjegyzés kívánkozik ide: egyfelől, okkal nevezhető ez az állapot absztrakt, történelmietlen, hipotetikus állapotnak, de ahogy McCormick is megjegyzi, e fogalom egy gondolatkísérlethez is hasonlítható, vagyis az emberi együttélés sajátos helyzetének egyfajta modellezése, amelyben az emberek közhatalom nélkül élnek (McCormick 1976: 63-76). Másfelől, amint arra a későbbiekben is kitérek, úgy tűnik, Hobbes tulajdonképpen kora „civilizált” polgárát vette alapul és emelte be a természeti állapotba, a pre-politikai körülmények közé.
} 


\section{TANULMÁNY}

zetben, hogy mi a „jó” önmaga számára. Az emberek egoista módon történő cselekedetei során kiderül azonban, hogy a racionálisnak tűnő egyéni döntések irracionális következménnyel járnak („kollektív” szinten), ami - sajátos Hobbes-i értelmezésben - a „mindenki háborúja mindenki elleni” állapothoz vezet (az egyéni döntések kollektív kihatásáról a későbbiekben lesz még szó).

Ennek elkerülésére egyetlen megoldás létezik: az emberek egymás közötti önkéntes megállapodása, melynek megtörténtével az emberi sokaság egyetlen személlyé „egyesül”. A rend és a béke viszont azért jöhet létre és maradhat fenn, mert a szuverén hatalma korlátlan, amelyet a szerződéselmélet háromlépéses szillogizmusa még inkább megerősíthet számunkra, ugyanis a két premissza és a következtetés értelmében:

- az ember annak köteles engedelmeskedni, amibe saját, szabadon meghozott döntése alapján beleegyezett (szuverén hatalom létrehozása);

- az ember beleegyezett (lemondott minden jogáról és felruház egy kiválasztottat);

- ebből adódóan az ember köteles engedelmeskedni (a szuverénnek) (McCormick 1976).

Az egymással összefüggő, egymásra ható, bonyolult viszonyrendszert alkotó tényezők figyelembevételével, nézzük tehát Hobbes művének logikai rekonstrukcióját:

1. Van egy elképzelt, közhatalommentes helyzet, amelyben vannak emberek, a maguk eredendő természetével, $\mathrm{T}\left\{t_{1}, t_{2^{\prime}} t_{3^{\prime}} \ldots t_{n}\right\}$. Itt olyan jegyek kerülnek előtérbe, mint az önzés $\left(\mathrm{t}_{1}\right)$; a bírvágy $\left(\mathrm{t}_{2}\right)$; a kapzsiság $\left(\mathrm{t}_{3}\right)$; ez utóbbi kettőhöz kapcsolódó hatalomvágy $\left(\mathrm{t}_{4}\right)$; a becsvágy (lelki erő, erős törekvés egy cél elérésére) ( $\mathrm{t}_{5}$ ); a biztonságvágy ( $\mathrm{t}_{6}$ ); továbbá, egy komparatív tulajdonság, az emberi képességek (fizikai, szellemi) viszonylagos egyenlősége $\left(\mathrm{t}_{7}\right)$ (ami a körülmények kapcsán is lényeges tényező); a racionalitás (ésszerű előrelátás) $\left(\mathrm{t}_{8}\right)$, a dicsvágy $\left(\mathrm{t}_{9}\right)$, végül, de nem utolsósorban a szerző által fokozottan kiemelt halálfélelem $\left(\mathrm{t}_{10}\right)$, illetve a halálfélelemmel szoros kapcsolatban álló önfenntartás $\left(t_{11}\right)$ ösztöne. A sort természetesen folytathatnánk tovább, akár a szerződéselmélet szempontjából kevésbé fontos, de nem elhanyagolható tulajdonságokkal (irigység, gonoszság stb.).

2. Az emberek $\mathrm{K}\left\{k_{1}, k_{2}, k_{3^{\prime}} \ldots k_{n}\right\}$ körülmények között élnek. Ennek kapcsán beszélhetünk a korlátozott természeti erőforrásokról $\left(\mathrm{k}_{1}\right)$; az élethez szükséges dolgok, javak szúkösségéről $\left(\mathrm{k}_{2}\right)$ (főleg, ha figyelembe vesszük a fokozódó demográfiai növekedésből adódó sűrű emberi környezetet); egyenlőségről $\left(\mathrm{k}_{3}\right)$; közhatalom hiányáról $\left(\mathrm{k}_{4}\right)$, az ebből adódó teljes szabadságról $\left(\mathrm{k}_{5}\right)$ stb.

3. E körülmények között, a maguk természetes mivoltukban az emberek $\mathrm{V}\left\{v_{1}\right.$, $\left.v_{2}, v_{3}, \ldots v_{n}\right\}$ módon viselkednek. Antropológiai körülményeikből adódóan az 


\section{TANULMÁNY}

emberek sajátos viselkedése közvetlenül függ össze alapvető természetükkel is. Egoista hajlamaiktól vezérelve és a javak szűkössége miatt az emberek versengenek $\left(\mathrm{v}_{1}\right)$ egymással, hatalomhalmozó törekvés $\left(\mathrm{v}_{2}\right)$ szövi át életüket, hiszen életük biztonságához, önfenntartásukhoz szükség van minél több hatalomra.

4. V módon történő viselkedésük következtében az emberek óhatatlanul az Á $\left\{a_{1}, a_{2}, a_{3}, \ldots a_{n}\right\}$ állapotba kerülnek. Ez egy olyan reménytelen állapot, amely tulajdonképpen a valós vagy potenciális egymásra támadás lehetőségét, az örökös viszálykodást és ellenségeskedést (á) vonja maga után. Ez az állapot a civilizált társadalom hiánya $\left(a_{2}\right)$, hiszen itt nincs földművelés, nincs hajózás, nincsenek szükséges eszközök, nincs tulajdon, se uralom (á), nincs törvény $\left(a_{4}\right)$; se igazságosság (á ${ }_{5}$ ). Ami van, az a bizonytalan tulajdon (á) (azok a javak, amelyeket az ember képes megszerezni, de csak addig, amíg azt képes megtartani), van káosz és mindenki háborúja mindenki ellen (á ${ }_{7}$ ).

5. Előre ez nem tudatosul bennük, de (adott ponton) az emberek ráeszmélnek, hogy ez az állapot elkerülhető lenne bizonyos $\mathrm{M}\left\{m_{1}, m_{2^{2}}, m_{3^{\prime}} \ldots m_{n}\right\}$ magatartásszabályok követésével. E szabályok Istentől eredő természeti törvények, „az értelem, a józan ész szabályai”, „a megmásíthatatlan és örökérvényü erkölcsi igazságok", amelyekből szám szerint 15 van: mindenki békére törekedjen, ameddig annak elérésére remény van $\left(\mathrm{m}_{1}\right)$; másokhoz való alkalmazkodás $\left(\mathrm{m}_{2}\right)$, a megkötött megállapodások teljesítése $\left(\mathrm{m}_{3}\right)$ stb. E szabályok eredője a Szentírás „aranyszabályán” nyugszik: „Amit nem kívánsz magadnak, ne tedd azt mással (Mt 7, 12; Lk 6, 31) (Hobbes 2001: 160). ${ }^{10}$

6. Az „aranyszabályba” tömöríthető magatartásszabályok csak és csakis az emberek kölcsönös megállapodásán nyugvó $\mathrm{A}\left\{a_{1}, a_{2}, a_{3}, \ldots a_{n}\right\}$ aktus következmé-

\footnotetext{
${ }^{10}$ A természeti törvények szerves részét képezik Hobbes elméletének, a kötelességen nyugvó morálfilozófiájának. A Hobbes-ra jellemző antropológiai pesszimizmus következménye, hogy a kezdeti állapotban az emberek nem tartják be Isten parancsait, vagyis a természeti törvények nem kötik az embert, ezért önmagában semmilyen vágy és érzelem, vagy az érzelmekből eredő cselekedet nem lehet bűn, mindaddig, amíg az emberek általános megegyezéssel nem emelnek maguk fölé egy szuverént, aki Isten parancsait kötelező erejűvé teszi, aki törvényt bocsát ki, és képes megtiltani a törvénybe ütköző cselekedeteket a zabolátlan vágyak és érzelmek kordában tartásával. Erre a lépésre az itt bemutatott logikai konstrukció következő fázisában kerül sor. A törvény és a jog fogalmainak, illetve a természeti törvények részletes elemzése a Leviatán fontos részét képezik, e tanulmány keretei között azonban csak utalás szintjén kerül sor e kérdésekre, mivel jelen írás nem a társadalmi szerződés aktusát és az állam létrejöttét helyezi az elemzés középpontjába. Ettől függetlenül csupán az utalás szintjén jegyzem meg azt a természeti törvény és a szerződés között dilemmát, amelyet többen is megfogalmaznak, ti. ha a végzetes állapot felismerése pillanatában az emberek „kötelességtudata” a természeti törvény jelenlétével magyarázható, akkor maga a szerződés veszti el központi jelentőségét (Stephen 2013: 193), ha viszont azt állítjuk a szerződésről, hogy a képzelt állapot logikai következménye, akkor viszont a természeti törvények vesztik el szerepüket (Laslett 1967: 466). Ezekről a gondolatokról a későbbiekben is lesz még szó.
} 


\section{TANULMÁNY}

nyeként tarthatók be, miután az ember felismeri, hogy az önpusztítást a természeti állapotból való kilépéssel megelőzheti. Az aktus értelmében az emberek kölcsönösen lemondanak természeti jogaikról $\left(a_{1}\right)$; és átruházzák azokat egyetlen személyre vagy testületre, korlátlan hatalmat adva a kiválasztott kezébe $\left(\mathrm{a}_{2}\right)$. Tulajdonképpen ez jelenti a társadalmi szerződést, ami a rendezett együttélés alapvető feltételeit hozza létre.

7. E társadalmi szerződésbe foglalt szabályok betartása tehát más körülmények között, $\mathrm{B}\left\{b_{1}, b_{2}, b_{3}, \ldots b_{n}\right\}$ berendezkedés révén biztosítható csak. Ez a berendezkedés az Állam, vagy Civitas, mellyel megszületik a Leviatán, „az a halandó isten, amelynek - a halhatatlan Isten fennhatósága alatt - békénket és oltalmunkat köszönhetjük" (Hobbes 2001: 197). A berendezkedés keretein belül: az uralkodó bármilyen cselekedetre feljogosítást kap $\left(\mathrm{b}_{1}\right)$; az uralkodó hatalmának forrása az alattvalók egymással kötött megállapodása, de ő nem részese a szerződésnek, ezért nem szeghet szerződést $\left(b_{2}\right)$; az uralkodó hatalma nagyobb, mint alattvalói összességének hatalma $\left(b_{3}\right)$; stb. ${ }^{11}$

\section{A természeti állapot}

Már korábban is utaltam rá, ${ }^{12}$ hogy Hobbes voltaképpen az angol polgárháború tapasztalataiból kiindulva vázolta fel a kiindulópontnak számító természeti állapotot, amelybe nem „természetes” embereket, hanem kora polgárait helyezte be, a maguk civilizált igényeivel, elvárásaival együtt. Ilyen értelemben - úgy tűnik - Hobbes elméletét „fordított” logikai sorrend jellemzi, hiszen az ok-okozati összefüggések érvsorozatában a szerző az okozatból indult ki és haladt az okok felé. A következtetés vált tehát kiindulóponttá, és innen haladt a szerző visszafelé a „kezdetekhez”, amelyre kellőképpen felépíthető - és egyben legitimálható - a Hobbes-i értelemben vett szuverén hatalom.

Ha figyelembe vesszük tehát a Hobbes-i mű szerkezeti felépítésének főbb logikai mozzanatait, akkor nem véletlenül fogalmazódik meg az elemzőben kérdések egész sora: Milyen kiindulóhelyzetre van szükség, hogy olyan hatalmat lehessen igazolni, amelyet Hobbes valóban szándékozott meghirdetni és legitimálni? Miért kell olyan-

${ }^{11}$ A rekonstrukció szerkezetének alapgondolatát Orthmayr Imre: Szerződéselmélet, aranykorelmélet, és társadalomtudomány (9-37.) c. írásából kölcsönöztem. Lásd: http://real.mtak.hu/34260/1/Orthmayr_Imre_Szerzodeselmelet_aranykorelmelet_es_tarsadalomtudomany_u.pdf

${ }_{12}$ Célszerűnek tartom itt megjegyezni, hogy a tanulmány során többszörös gondolatismétléssel fog szembesülni az olvasó. Ezt akár „hibaként” is elkönyvelhetnénk, ne feledjük azonban, hogy Hobbes-tól egyáltalán nem idegen ez a technika. A Leviatán egyetlen (tizenharmadik) fejezetében például a szerző nem kevesebb, mint hat alkalommal tért vissza arra az alapvető gondolatra, hogy „közhatalom hiányában” mi minden van jelen (háborút okozó tényezők), és mi minden nincs jelen (békét elősegítő körülmények). A szerző bizonyára nem a túlzott ismétlés csapdájába esett, hanem ellenkezőleg, szándékosan térhetett vissza múve egyik központi gondolatára, annak újra meg újra történő fokozott hangsúlyozásáért. 


\section{TANULMÁNY}

nak lennie ennek a kezdeti állapotnak, amilyennek Hobbes valójában leírta azt? Célja elérése érdekében voltaképpen milyen természeti állapotot sikerült az olvasó elé tárnia, és vajon ez milyen mértékben meríti ki a szerzői szándékot?

A logikai rekonstrukció alapján világosan körvonalazódik Hobbes elméletének fejlődési íve, melynek kiinduló fázisára az ember - a maga komplex és sajátos természetével - és az őt körülvevő antropológiai körülmények bonyolult egyvelege jellemző. Ez a környezet közhatalomtól mentes, de - nem kötelező erővel bíró - természeti törvényekkel átszőtt puszta természetes állapot. A továbbiakban két, egymáshoz kapcsolódó, egymással kölcsönös viszonyban lévő - a bevezetőben is megfogalmazott - szempont alapján szeretném megközelíteni az eredeti helyzetet, hogy rámutassak annak kevésbé egyértelmú jellegére és komplexitására.

Először, ha Hobbes filozófiájának egyik erénye nem a történelmi „igazság” feltárásában, hanem mondandójának meggyőző erejében rejlik, akkor kihívó kérdésként tételeződik, hogy vajon mekkora meggyőző erővel bír, és mennyire hiteles az absztrakt, hipotetikus természeti állapot a 17. század olvasója számára, figyelembe véve az „átmeneti kor” filozófusának két alapvető szándékát: egyrészt, kifejteni az állammal és a hatalommal kapcsolatos elméletét (az írás szándéka), másrészt úgy ábrázolni az emberi természetet és e természethez köthető eredeti állapotot, hogy az a lehető legnagyobb mértékben alapozza meg a szuverén hatalom szükséges voltát, illetve hogy ezen keresztül a lehető leghatékonyabban győzze meg a szerző a kor olvasóját filozófiájának „igazáról”, elméletének hitelességéről (meggyőzés szándéka).

E szerzői szándék kapcsán merülhet fel az a kérdés, hogy egyáltalán állt-e, állhatott-e Hobbes szándékában a Teremtés története és az általa ábrázolt természeti állapot közötti analógia implicit elfogadása.

Másodszor, az előző szemponttól nem függetlenül, indokoltnak tűnik két alapvető kérdés felvetése: Pontosan milyen tényezők összjátéka vezet (A Leviatán szoros szövegolvasata alapján) a katasztrófához, azaz a mindenki mindenki elleni háborújához? Valóban axiomatikus-e a totális háborúba torkollás, ahogy azt Hobbes látta és láttatni szándékozta?

\section{Teremtés története versus Természeti állapot}

Általános megközelítésben elfogadott, hogy elméletének kezdeti fázisát Hobbes olyan alapszerkezetre építette, mely - a szerző szándékaival összhangban - alátámasztja a totális hatalom létrehozásának szükséges voltát. A részkérdések szintjén kérdés azonban, hogy vajon hogyan szándékozta Hobbes bemutatni a hipotetikus állapot egyes mozzanatait (kiinduló helyzet, emberi természet, antropológiai körülmények stb.) annak érdekében, hogy minél hitelesebb képet adjon hatalomelméletének alapjáról. Ez azért sem lehetett könnyű feladat, mert ahogy korábban is említettem, Hobbes egyfelől komoly társadalmi-gazdasági-politikai átalakulások szemtanújaként, a keresztényi és a természettudományok eredményein alapuló világkép 


\section{TANULMÁNY}

közötti átmeneti korszak filozófusa volt, másfelől, mert művében több helyen is kétértelmű gondolatokkal, ellentmondásokkal, hiányérzetet keltő szövegrészekkel szembesülhet az elemző.

Jelen tanulmányban nem célom az analitikus és kontextuális módszerek, és e módszerek, elsősorban oxfordi ${ }^{13}$, illetve cambridge-i ${ }^{14}$ hívei írásainak tüzetes elemzése, és a Hobbes-i megállapítások „szándékolt illokúciós” ${ }^{15}$ vonásának részletes kifejtése sem. Úgy gondolom azonban, érdemes - legalább az utalás szintjén - említést tenni ezekről, hiszen e módszerek (néha feltételezett „elavultságuk” ellenére) hozzásegíthetnek a természeti állapot néhány dilemmájának megfelelőbb feltárásához.

A szerzői szándék kapcsán Quentin Skinner ismert kérdésfelvetése juthat eszünkbe: „Mi lehetett egy adott történelmi szereplő szándéka egy adott megállapítás megtételével?” (Skinner 1997). Skinner felhívja a figyelmet arra, hogy a szerző megfogalmaz és leír egy szöveget (ez tehát egy szándékos tett), amely leginkább valamilyen ok vagy okok következményeként érthető meg. A Leviatán kapcsán, lássuk be, a mű megírásának szándékán túl, nem tünik meglepőnek - a mű megírásával való szándékként - a következtetés a rend iránti szenvedélyéről ismert filozófus részéről, hiszen hihetőnek tűnik, hogy a kezdeti állapot áldatlansága eleve legitimálja a szerződéssel létrehozott, rendet és békét teremtő szuverén hatalmat.

Ha tehát elfogadjuk, hogy Hobbes filozófiájának egyik legalapvetőbb erénye annak meggyőző erejében rejlik, akkor joggal feltételezhetjük, hogy Hobbes szándékában kellett állnia magának a természeti állapotnak is a lehető legelfogadhatóbb és leghihetőbb bemutatása, még akkor is, ha a szerző nem történelmi tényeken, hanem absztrakción nyugvó helyzetet tárt az olvasó elé.

Ne feledjük, egy „üzenet” átadása kapcsán nemcsak a szerző fontos, hanem az olvasó is, és a szöveg jelentését nem egymagában a szerző vagy pusztán a szöveg, és nem is egyik vagy másik olvasó, hanem elsősorban az „értelmező közösség” (interpretive community) szabja meg (Fish 1980: 14), amelynek a szerző is részese. ${ }^{16} \mathrm{Ha}$ ez elfogadható, akkor szerzőt és olvasót nem lehet egymástól elszigetelten kezelni, hiszen az értelmező közösség mindkettőt magába foglalja, és e közösség befolyásolja, hogy mit olvas, és miként értelmez az olvasó. Azt is mondhatnánk, hogy a szerző - feltételezhetően - maga elé képzeli az olvasót, és művét befolyásol(hat)ja az olvasó elvárása és kívánsága (is). ${ }^{17}$ Ellenkező esetben a mű kevésbé tűnik hitelesnek az

\footnotetext{
${ }^{13}$ Gregory Kavka, John W. Gough, David Gauthier és mások írásait említhetném elsősorban.

${ }^{14}$ Q. Skinner mellett mindenekelőtt John G. Pockok, Richard Tuck és John Dunn munkáira gondolok.

${ }^{15}$ A nyelv lokuciós és illokuciós jellegének elemzését lásd Austin 1990. E kérdés nagyszerű összegzését lásd Skinner: 1997: 7-53, különösen 44-53.

${ }^{16}$ Ahogy az alapvető politikai kifejezések fogalomtörténetének egyik megalapozója R. Koselleck is állítja, egy korszak eszméje, uralkodó szellemisége nem azonos a szellem kimagasló embereinek meglátásaival, az jóval inkább „közösségi termék” (és a koreszmét - Koselleck szerint - szavak hordozzák).

17 „Writing is conditioned by the readers' expectations and desires” (Sharpe 2000: 59).
} 


\section{TANULMÁNY}

„interpretatív közösség” szemében. Hobbes bármennyire is különc filozófus a kortársak szemében, akkor is nehéz lenne őt teljesen kiszakítani ebből a közösségből.

Azt hiszem, nem túlzás azt feltételezni, hogy a 17. század embere többnyire a Biblia és a Szentírást magyarázó szövegek prizmáján keresztül olvasta a különböző filozófiai írásokat is, és ez vonatkozhat Hobbes művére is. Szekuláris törekvései ${ }^{18}$ ellenére ez nem lehetett meglepő Hobbes számára, mi több, akár szándékában is állhatott „beengedni” a Teremtés és a Bünbeesés történetét az általa felvázolt természeti állapotba, műve hitelességének növelése érdekében.

Erre utalhat Tom Sorell, mondván, úgy tűnik, Hobbes eleve feltételezte, hogy a Bünbeesés bibliai története egyfajta közös alapot jelenthet közte és saját műve olvasói között (Sorell 1986: 34). ${ }^{19}$

Találó lehet Sheldon Volin idevágó gondolata, melynek értelmében a Hobbes által lefestett természeti állapot a Teremtés és a Bünbeesés történetének egyfajta politikai változata, „világi analógiája”, ugyanis a valamikori politikai rend teremtette állapotot (értsd az angol polgári forradalom előtti időszakot) az emberek szerették, elvesztették, aztán annak visszaállítására törekedtek (Wolin 1960: 264).

Leo Rauch is felhívja a figyelmet arra, hogy Hobbes politikaelmélete tulajdonképpen egy vallási mitológia szekuláris visszatükrözése, melyhez hozzáad a szerző néhányat a maga mítoszaiból (Rauch 1991: 89-102).

Hobbes természeti állapota és a Bünbeesés közötti hasonlóságra mutat rá Norberto Bobbio is, aki azt állítja, hogy Szent Ágoston és Luther szerint az állam tulajdonképpen megoldás a bűnbeesésre, míg Hobbes szekuláris verziójában, véli Bobbio, a hatalom „nem a bűn orvoslásának, hanem az indulatok kordában tartásának eszköze" (Bobbio 1993: 68).

Michael Oakeshott szerint Hobbes egy új, világi mítoszt alkotott az emberiség bűnbeesése és megváltása terén: Szent Ágostontól kölcsönözhette a mindenki mindenki elleni háborújának gondolatát, ugyanis Ágoston a Káin és Ábel példáján keresztül érzékeltette az egyetemes ellenségeskedés eszméjét (Oakeshott 1975: 56, 58, 82-83) és Hobbes maga is tett említést erre az ellenségeskedésre. ${ }^{20}$

${ }^{18}$ Szekuláris törekvései miatt nevezte őt több kortársa is „antiklerikális” gondolkodónak, mi több, még az „ateista” jelzőt is ráragasztották, ami azért szokatlannak számít a 17. században. Lehet, hogy túlzás ez a minősítés, az viszont kijelenthető, hogy a lelkiismeretnek és a vallás számos kérdésének kihívó kezelési módja olvasható ki a Leviatánból.

19 Megjegyzendő, hogy Hobbes korabeli kritikusai úgy tekintettek az emberre, amilyennek lennie kellene, miközben Hobbes egyszerűen az emberi természetet a maga „valóságában” tárta fel, úgy, ahogy o látta és láttatni akarta (Thorton, 2005: 5). Ezért nem az Édenre, hanem inkább a Bűnbeesésre helyeződik a hangsúly.

${ }^{20}$ A Káin és Ábel „egyetemes” jellegű ellenségeskedésére Hobbes nem a Leviatán eredeti (1651), hanem egy későbbi (1688) latin kiadásában tett utalást, mondván, hogy Káin nem merte volna megölni Ábelt közhatalom léte mellett, mely hatalom büntetést szabott volna ki rá tettéért (Curles [ed.] 1994). A Káin és Ábel története a totális háború alátámasztására jól példázza a Szentírás sajátos retorikával történő megközelítését (Rethorical use of Scripture) (Thorton 2002). 


\section{TANULMÁNY}

Quentin Skinner is megjegyzi, hogy akár párhuzam is vonható a bűnbe eső ember és Hobbes feltételezése között, amelynek értelmében az ember „ösztönös gonoszsága" egyfajta politikai előfeltételezés.

A Teremtés és a Hobbes-i természeti állapot összekapcsolása olvasható ki Pat Moloney soraiból is, ugyanis Hobbes, véli Moloney, „újraolvasta” a Teremtés könyvét, és ahogy „Ádámnak nem volt szüksége isteni utasításra”, úgy Hobbes-nak „nem volt szüksége a Paradicsom történetére” (Moloney 1997: 242-266). Moloney szerint az sem kizárt, hogy az „átmeneti” korszak filozófusa új alapokra helyezte a Teremtés hagyományos értelmezését, ezért is akadt annyi kritikusa (Moloney 1997: 243).

Mindezek alapján felmerül egy (külön tanulmányt érdemlő) kérdés: Mennyire lehetett Hobbes vallásos? Jelen írás szempontjából ennél is fontosabb: mennyire lehet vallásos töltetű a Hobbes-i természeti állapot?

Az első kérdés kifejtése semmiképp nem célja e tanulmánynak, ${ }^{21}$ egy rövid megjegyzés erejéig azonban annyi bizonyos, hogy a válasz nem billen annyira egyértelműen az egyik vagy a másik oldalra, hiszen Hobbes nem tagadta a vallást, de azt pusztán emberi találmánynak vélte, mi több, a katolikus egyházra, mint a világi hatalom ellenében, külső hatalomként fellépő intézményre tekintett. A vallással kapcsolatos Hobbes-i gondolatok (Tizenkettedik fejezet) ezért nem véletlenül keltettek felháborodást a 17. században. Már a fejezet indító mondata elgondolkodtató: „Mivel a vallásnak csak emberi megnyilvánulásai és gyümölcsei vannak, nincs okunk kételkedni abban, hogy a vallás magja is csak az emberben található meg" (Hobbes 2001: 139). Ha bármit lát az ember, mondja Hobbes, aminek kezdete van, akkor joggal feltételezi, hogy annak oka is kell, hogy legyen. De ha az ember „a dolgok valódi okai felől nem tud bizonyosságot szerezni, akkor feltételezi az okokat” (Hobbes 2001: 139), vagy saját képzelőerejére támaszkodva próbálkozik magyarázatokkal. Az okok nem ismerete azonban félelmet kelt az emberben, és ebből Hobbes az ókori költőkre hivatkozva vonja le a maga indulatokat keltő következtetését is: „Az isteneket az emberi félelem teremtette".22

A természeti állapot esetleges vallásos töltete kapcsán nem kizárt, hogy Hobbes ez alkalommal is egy sajátos csapdába („átmeneti” állapotba) került. Egyik oldalról azért, mert aligha állhatott a szerző szándékába „túlzottan” átemelni elméletébe a Teremtés hagyományos értelemben vett (idilli állapotot jelentő) történetét (Thorton 2005: 6). Ez egyáltalán nem meglepő, ha arra gondolunk, hogy Hobbes arra a kiinduló tételre építette hatalomelméletét, hogy az erőszak a természetes ember vele-

${ }^{21}$ Hobbes vallással kapcsolatos gondolatainak részletesebb kifejtése akkor lenne indokolt, ha műve átfogó elemzését tűznénk célul, vagy ha elsősorban Hobbes és a vallás kérdéskörét vizsgálnánk. Ezt a kérdést is érintve a Leviatán rövid, de átfogó összegzését lásd többek között: Ludassy 1999: 9-60.

${ }^{22}$ Devin Stauffer szerint a Leviatánból kiérződik Hobbes antiklerikális nézete (Stauffer 2010: 868879). Nem véletlen, hogy vallási nézetei miatt nem voltak ritkák az egyházi támadások, kortársi felzúdulások. Hobbes és a vallás terén lásd még Miller 1988: 400-425. 


\section{TANULMÁNY}

járója, ezért az erőszakkal (háborúskodással) telített élet eredendően jelen lévő, az ősidőktől fennálló állapot.

Másik oldalról pedig azért kerülhetett Hobbes csapdába, mert a Teremtés könyvének „túlzott” elutasítása (netán a Bibliával való fokozott szembenállása) művének hitelét, elfogadottságát áshatja alá, mindenekelőtt a kor olvasója szemében. Úgy tűnik tehát, hogy valahol a két pólus között „lavírozott” a szerző ebben a kérdésben: hitelessé szándékozhatta tenni művét, ezért explicite nem határolódhatott el teljes mértékben a vallás, a Biblia világától, másfelől azonban a Teremtés és Bünbeesés történetét sem karolhatta fel maradéktalanul, mivel alapvető szándéka az Istentől független állami hatalom legitimációjának „tudományos” bizonyítása volt. ${ }^{23}$ Természetesen ebből a célkitűzésből nem következik automatikusan a Szentírástól való teljes elhatárolódás a természeti állapot ábrázolásában, a szuverén hatalom létrehozásának aktusát azonban már vallásmentes, kizárólag emberi (világi) alkotásként kellett megjelenítenie, a feltételezett szerzői szándék értelmében, ${ }^{24}$ annál is inkább, mert Hobbes alapvető célkitűzései közé tartozott a lelkiismereten nyugvó hitvitákból fakadó, polgárháborút gerjesztő konfliktusoknak az állam életéből való kirekesztése is.

\section{A totális háború elkerülhetetlensége}

Ami a háborúba torkolló viszálykodás okait illeti, néha rutinszerűnek tűnik az emberi természetben megtalálható és a szerző által is kiemelt három fő okra hivatkozni: versengés, bizalmatlanság, dicsvágy.

„Az első arra indítja az embert, hogy nyereségért, a második, hogy biztonságért, a harmadik pedig, hogy hírnévért törjön rá másokra. Az első azért alkalmaz erőszakot, hogy uralkodhassék mások személye, felesége és jószága felett, a második, hogy mindezt megvédje, a harmadik pedig semmiségek, egy szó, egy mosoly, egy eltérö vélemény vagy a lebecsülésnek bármilyen más jele miatt, amely vagy közvetlenül ellene irányul, vagy rossz fényt vet rokonaira, barátaira, hazájára, foglalkozására vagy nevére" (Hobbes 2001: 155).

A szerző szerint ezekből egyértelműen következik, hogy „ameddig nincs közhatalom, amely mindenkit kordában tart, addig az emberek olyan állapotban élnek, amit

\footnotetext{
${ }^{23}$ A modern tudományok eredményeit tárt karokkal fogadó gondolkodó szekuláris törekvései kézzel foghatóak, ezért is vallja Hobbes teljes meggyőződéssel, hogy mivel Isten törvényei nem képesek kordában tartani az emberi indulatokat - nem elég „erősek” ahhoz, hogy kössék az embert -, szükség van világi szuverén hatalomra a rend és a béke érdekében.

${ }^{24} \mathrm{Az}$ állami hatalom emberre visszaeredeztető forrásával Hobbes tulajdonképpen az isteni erkölcsön alapuló állam helyébe a modern jogállam eszméjét jelenítette meg.
} 


\section{TANULMÁNY}

háborúnak nevezünk, ez pedig mindenki háborúja mindenki ellen" (Hobbes 2001: 155-156). ${ }^{25}$

A magam részéről úgy vélem, ez a magyarázat mindenképp kiegészítésre vagy inkább pontosításra szorul. Természetesen nem azt állítom, hogy Hobbes maga „tévedett" saját szövege megfogalmazásában, jóval inkább azt vallom, hogy a háborút generáló viszálykodás - fentebb is kiemelt - okai nem a háború magyarázatának kiindulópontjai (ahogy azt többnyire szokás értelmezni), azok inkább az emberi természet néhány alapvető jegyének következményei. Ha ez elfogadható, akkor a versengés, a bizalmatlanság, illetve a dicsvágy szerves részei ugyan, de nem kezdeti okai a háborúnak, ezért nem nyújtanak teljes és átfogó magyarázatot arra nézve, hogy miért is tűnik axiomatikusnak Hobbes müvében, hogy a hatalommentes állapot embere a totális háború felé vezeti önmagát és embertársait.

A Hobbes-i természeti állapot háborúba torkollásának elkerülhetetlensége ${ }^{26}$ megítélésem szerint - az emberi természet és az antropológiai körülmények (sajátosságok) együttes hatásával magyarázható. Ahhoz tehát, hogy pontosabb (és teljesebb) képet kapjunk a háborús állapot okairól, a versengés, a bizalmatlanság, illetve a dicsvágy előzményeit kell górcső alá vennünk. Abban az esetben sikerül csak megfelelő mértékben kimutatnunk, hogy a szuverén uralkodó (korlátlan) hatalomgyakorlásának legitimálásához Hobbes kellő átgondolással ábrázolta a hipotetikusnak vélt kezdeti állapotot, ha a teljes szabadsággal ${ }^{27}$ rendelkezó és értelemmel felruházott emberek közötti egyenlőségből indulunk ki. ${ }^{28}$

${ }^{25}$ Hobbes sajátos értelmezése szerint a háború nemcsak csatákból vagy harci cselekményekből áll, hanem a közismert harci szándékokból is (Hobbes 2001: 156).

${ }^{26}$ A félreértés elkerülése érdekében jegyzem meg, hogy amikor a Hobbes-i értelemben vett természeti állapotról beszélek, akkor eleve olyan állapotra gondolok, amelyben jelen van az „ész diktálta parancs”, az „értelem előírása”, mely azonban nem köti az embert. A természeti törvények tényleges követésére a mindenkire kötelező erővel bíró szuverén hatalom létrejöttével kerülhet csak sor. Ilyen értelemben, a pre-politikai állapotban inherensen benne vannak a háborúhoz szükséges feltételek (az emberi természeten túl), ezért nem taglalom külön a közhatalom hiányát, mint a totális háború alapvető okát.

${ }^{27}$ Hobbes szerint a szabadság mindenki számára azt jelenti, hogy „önnön erejét saját akarata szerint saját lényének, vagyis életének megoltalmazására használhatja fel, s következésképpen mindent megtehet, amit e cél érdekében saját megítélése és értelme szerint a legelönyösebbnek tart” (Hobbes 2001: 158-59). Leegyszerűsített formában vagy a szó eredeti értelmében szabadságon „a külső akadályok távollétét értjük", de ha mégis vannak akadályok, amelyek felemésztik az ember erejének egy részét, akkor sem gátolhatják meg abban, hogy „ereje megmaradó részét megítélésének és értelmének parancsa szerint használja fel" (Hobbes 2001: 159).

${ }^{28}$ Az emberből kiindulva, Hobbes olyan antropológiai körülmények közé helyezi a szenvedélyeitől vezérelt individuumot, hogy az megfelelő alapot nyújtson államelmélete számára. A természeti állapot antropológiai sajátosságai lehetnek: korlátlan szabadság (az ember mindent megtehet, amire képes, élete védelmezéséért); az emberek közötti egyenlőség (viszonylag egyenlő testi és szellemi képességek, aminek köszönhetően senki nem érhet el magabiztos előnyöket másokhoz viszonyítva); a természetes értelem (inkább individuális, nem pedig kollektív); a testvériség, szolidaritás, együttérzés teljes hiánya (Hobbes elvágta annak lehetőségét, hogy az emberek közötti racionális kommunikáció feloldhassa a közöttük fennálló konfliktust); a közös érdekek racionális be nem látása (a végzetet jelentő felismerést megelőzően az emberek nem képesek kollektív érdekekben gondolkodni) (Tóth 2020). 


\section{TANULMÁNY}

Itt nem pusztán arról van szó, hogy az emberek közötti egyenlőség középpontba állításával Hobbes egyenesen szembe menne a hierarchikus rend rendeltetésszerű egyenlőtlenségével, a társadalmat átszövő alá-, és fölérendeltségi viszonyokkal, hanem elsősorban arról, hogy Hobbes elmélete aligha állna meg a lábán az emberek közötti eredendő, viszonylagos egyenlőség nélkül a szűkös javak világában. Úgy tűnik, hogy az önfenntartásból, mint a legalapvetőbb ösztönből kiindulva, az emberek közötti egyenlő testi és szellemi képességek, és ezekre alapozva az ember önző természete, az önzésből fakadó (és gyakran kapzsiságba átcsapó) bírvágy, illetve az élethez szükséges jószágok szúkös voltának közös hatása - közhatalommentes közegbe illesztve - képezi Hobbes államelméletének megalapozott kiindulópontját.

Az egyenlőség nem a szó legszigorúbb értelmében értendő Hobbes-nál, hiszen „az egyik embernek a másiknál olykor nyilvánvalóan izmosabb teste és fürgébb a szelleme", de az egyenlőség mégis érvényes, mert:

„Mindent összevéve az ember és ember közti különbség nem annyira jelentős, hogy ilyen alapon az egyik ember olyan elönyöket követelhessen magának, amelyekre egy másik éppoly joggal igényt ne tarthatna. Mert ami a testi erôt illeti, még a leggyengébb embernek is elég ereje van ahhoz, hogy a legerősebbet megölje - akár cselvetés útján, akár pedig olyanokkal szövetkezve, akik hozzá hasonló veszélyben forognak. És ami a szellemi képességeket illeti, úgy vélem, hogy e téren az emberek közti egyenlöség még nyilvánvalóbb, mint a testi erő terén." (Hobbes 2001: 153)

Világos, hogy Hobbes nem az abszolút értelemben vett egyenlőségről beszélt, bizonyára nem is volt szüksége arra, megfelelőnek tűnt ugyanis a laza értelemben vett, a realitáshoz közelebb álló egyenlőség (jelentéktelen mértékű egyenlőtlenség), amely épp megfelel a célnak: ha az emberek közötti különbségek nem lényegesek, hanem szerény mértékűek, akkor a politikamentes állapotban senki nem érezheti magát teljes biztonságban, mivel mindenki potenciális (és valós) veszélyforrást jelenthet mindenki más számára. ${ }^{29}$ Hobbes hatalomelméletében alapvetően szükség van e sajátos antropológiai körülményre, mivel csak így lehet azt az átfogó, mindenkire kiterjedő viszálykodást jelentő állapotot ábrázolni, mely a totális háború irányába mutat.

A képességek viszonylagos egyenlőségéből a szerző az önfenntartáshoz szükséges dolgok megszerzésének esélyegyenlőségére, illetve a célok elérésére irányuló reményegyenlőségre helyezte a hangsúlyt és lássuk be, nem véletlenül, hiszen a szükös javak - akár egymagában, akár másokkal összefogva - megszerzésére irányuló

${ }^{29} \mathrm{Ez}$ a gondolat meg is fordítható: az egymással szemben álló emberek közötti egyenlőtlenségeknek oly szerényeknek kell lenniük, hogy senki ne érezhesse magát biztonságban. 


\section{TANULMÁNY}

egyenlő remény olyan mértékű motivációt kölcsönöz a természetes ember számára, mely az önzéssel párosulva mindenképp a háborús állapot előidézéshez járul hozzá. Az esélyek és a remény egyenlőségének kihangsúlyozása megfelelő kiindulópontnak tűnik a mindent átfogó versengés, a bizonytalanság és a dicsvágy számára, megteremtve ezzel a szerző által ábrázolandó állapot alapvető előfeltételeit.

Az emberek közötti egyenlőség mellett Hobbes államelméletének megalapozásához szükség van tehát az egyáltalán nem következetes emberi önzésre is, amely az önfenntartási törekvésben arra készteti az embert, hogy másokra való tekintet nélkül minél biztonságosabb helyzetet teremtsen önmaga számára. Ennek záloga a veszély megelőzése, vagyis az, hogy „erővel vagy csellel mindenkit leigázzon, akit csak tud, míg aztán már nem lát maga körül olyan nagyhatalmat, amely fenyegethetné" (Hobbes 2001: 154). Logikai következmény, hogy a biztonság növelése hatalomhalmozáshoz ${ }^{30}$ (bírvágy) vezet, erre azonban nemcsak biztonsága, hanem dicsvágya (mások fölé kerekedési törekvése és ezzel önmaga mások általi elismertetésének vágya) is készteti az embert, aki azt szeretné, hogy „embertársai úgy értékeljék, mint ahogy ő értékeli önmagát", és hogy minél több megbecsülést legyen képes kicsikarni, ha kell, erőszakkal (Hobbes 2001: 155).

Az önérdekeit követő ember hatalomhalmozási törekvése azonban abszurd, mivel állandó törekvése ellenére sem képes annyi hatalmat felhalmozni ebben az állapotban, hogy képes legyen önmagát sokáig fenntartani (Ennek nincs tudatában a természetes ember, mindaddig, amíg nem jön el a „felismerés” nagy pillanata). Mi több, önnön hatalma növelésére irányuló törekvése nem mindig történik a szükségletekkel összhangban, ugyanis „akadnak olyanok, akik hatalmuk fitogtatásában örömüket lelik, és hódításaikban messzebbre mennek, mint ahogy azt biztonságuk megkívánja" (Hobbes 2001: 155). Ezek alapján úgy tűnik, önzése, bírvágya és dicsvágya mellett a természetes embert a kapzsiság is jellemzi (közvetlenül kapcsolódva a dicsvágyhoz), melynek késztetésére állandóan többet szeretne megszerezni, mint amennyi biztonságához szükséges lenne. Ez viszont aligha eredményez „békés” versengést: a biztonságos versenyszellem helyett a dolgok megszerzése többnyire agresszivitásba torkolló támadás útján valósul meg.

Ilyen értelemben az önfenntartó emberek lehetnek támadók vagy védekezők. Az előbbiek komoly veszélyt jelentenek az utóbbiakra, az utóbbiak viszont hamar változtatásra kényszerülnek, annak ellenére, hogy ők „szívesen élnének nyugalomban szerény határaikon belül, de a puszta védekezésre támaszkodva huzamosabb ideig nem tudnak ellenállni”, ezért ők is arra kényszerülnek, hogy „támadás útján növeljék hatalmukat" (Hobbes 2001: 155).

${ }^{30}$ Hobbes szerint a hatalom „általánosságban véve azokat az eszközöket jelenti, amelyek valakinek egy adott pillanatban valamely jövőbeli, jónak tetsző dolog eléréshez rendelkezésére állnak" (Hobbes 2001, 120-121). 


\section{TANULMÁNY}

Mintha feloldhatatlan ellentmondással szembesülnénk: a természetes ésszel rendelkező ember önfenntartásra, biztonságra, kényelmes életre, azaz a maga javára törekszik, mégis bizonytalanság és önpusztítás felé közeledik a másokkal való versengésben. Úgy tűnik, újból az egyén és közösség örökzöld dilemmájának felerősödését tapasztalhatjuk, amelyben nem csak az indulataitól és szenvedélyeitől vezérelt ember mond ellent önmagának, és önnön céljainak abszurd dolgok megtételével, hanem az ellentmondásokkal telített természeti állapot is megtagadja önmagát azzal, hogy a végzethez közeledve önnön felszámolásán munkálkodik (Horváth 2001: 134).

Ebből az abszurd helyzetből való kilábalásra, a csapdaszerű ellentmondás (amelynek értelmében a biztonságos, kényelmes életre törekvés tulajdonképpen az önpusztítás állapota felé sodorja az embert) feloldására a politikamentes állapotban maradással - Hobbes szándékával összhangban - nincs megoldás. Nem tűnik meglepőnek e szerzői következtetés, hiszen az eredeti állapotról sötét képet festő filozófus antropológiai pesszimizmussal a tarsolyában bizonyítja, hogy fokozott egoizmusa miatt az ember egymaga nem képes kordában tartani indulatait, szenvedélyeit külső segítség nélkül. Hobbes tehát egyáltalán nem törekedett a természeti állapoton belüli abszurd helyzet önmagában való felszámolására, ellenkezőleg, annak fokozott fenntartására törekedett, ami abból is kiérződhet, hogy határozottan szembe ment a zoon politicon vagy a homo societas híveivel, újból és újból kiemelve, hogy a mindenkire kötelező erejű közhatalom hiányában az önző ember képtelen társadalmi életre. Ezzel a kanti „társiatlan társiasság” fokozottabb verziója juthat az olvasó eszébe: az ember egyszerre individuum és társas lény, egyszerre önző és altruista, ennek viszont végzetes konfliktus lehet az ára.

Úgy tűnik, a békés életre törekvés ellenére a természetes ésszel rendelkező pre-politikai ember azért (is) kerül ebbe a sajátos csapdába, mert racionálisnak tűnő egoista döntéseit egyéni szinten hozza meg, másokra való tekintet nélkül, cselekedetei azonban társas szinten érzékelhető irracionális következményekkel járnak. ${ }^{31}$ Más szavakkal, az ésszerűnek és megfelelőnek tűnő egyéni cselekedetek végül is (társas szinten) konfliktusfokozó tényezők. A természeti állapot e központi dilemmáját analitikus megközelítésben, a modern játékelmélet egy közismert példáján, a fogoly dilemmán keresztül szeretném valamelyest érzékeltetni.

Tételezzük fel, hogy a természeti állapot két szereplője, János és István két különböző módon viszonyulhatnak egymással szemben: békés vagy agresszív magatartás (közeledés) révén. Táblázatba foglalva, a következő (logikailag elfogadhatónak tűnő) lehetőségekről beszélhetünk:

\footnotetext{
${ }^{31}$ Annak ellenére, hogy az egyén - közösség, individuum - társadalom viszonya más értelmezést nyer napjainkban, mint Hobbes korában, a modern döntéselméletben is kénytelenek vagyunk szembesülni e dilemmával, hiszen a Kenneth Arrow által is megfogalmazott tétel értelmében a döntéselmélet egyik paradoxonja, hogy az egyéni racionális döntések összegzése irracionális kollektív döntést eredményeznek.
} 


\section{TANULMÁNY}

1. táblázat. Békés és agresszív magatartás a természeti állapotban

\begin{tabular}{|c|c|c|c|}
\hline \multicolumn{2}{|c|}{} & \multicolumn{2}{|c|}{ JÁNOS } \\
\cline { 3 - 4 } \multicolumn{2}{|c|}{} & Békés magatartás & Agresszív magatartás \\
\hline \multirow{3}{*}{ ISTVÁN } & $\begin{array}{c}\text { Békés } \\
\text { magatartás }\end{array}$ & $\begin{array}{c}80 \% \text {-os túlélési esély } \\
\text { mindkét fél számára* }\end{array}$ & $\begin{array}{c}20 \% \text {-os túlélési esély Istvánnak, } \\
95 \% \text {-os túlélési esély Jánosnak }\end{array}$ \\
\cline { 2 - 5 } & $\begin{array}{c}\text { Agresszív } \\
\text { magatartás }\end{array}$ & $\begin{array}{c}95 \% \text {-os túlélési esély Istvánnak, } \\
20 \%-0 s \text { túlélési esély Jánosnak }\end{array}$ & $\begin{array}{c}50 \% \text {-os túlélési esély } \\
\text { mindkettójük számára }\end{array}$ \\
\hline
\end{tabular}

Forrás: Saját szerkesztés

* Mivel a természeti állapotban az emberek viszonylag egyenlő fizikai és szellemi képességekkel rendelkeznek, azonos helyzetben túlzás nélkül adhatunk nekik azonos túlélési esélyt.

Istvánra való tekintet nélkül János a következőképpen gondolkodik:

Első lehetőség: „Ha István békés, és én is békés vagyok, akkor 80\%-os a túlélési esélyem. Ha István továbbra is békés, én viszont agresszív vagyok, akkor a túlélési esélyem 95\%-osra növekedik. Előnyösebb tehát agresszívnak lennem” - mondja János.

Második lehetőség: „Ha István agresszív, én meg békés vagyok, 20\%-os túlélési eséllyel kell beérnem. Ha István agresszív és én is az vagyok, a túlélési esélyem 50\%-osra növekszik. Ez esetben is előnyösebb agresszívnak lennem" - véli János.

Jánosra való tekintet nélkül István - analóg módon - a következőképpen gondolkodik:

Első lehetőség: „Ha János békés, és én is békés vagyok, akkor 80\%-os a túlélési esélyem. Ha János továbbra is békés, én viszont agresszív vagyok, akkor a túlélési esélyem 95\%-osra növekedik. Előnyösebb tehát agresszívnak lennem" - győzi meg magát István.

Második lehetőség: „Ha János agresszív, és én békés vagyok, nem sok esélyem van a túlélésre (20\%). Abban az esetben viszont, ha támadására agresszióval válaszolok, akkor lényegesen nagyobb lesz a túlélési esélyem (50\%). Ez esetben is előnyösebb számomra az agresszív magatartás" - következtet István.

Világos, hogy a másik félre való tekintet nélkül (önzés), illetve külső ellenőrző tényező (közhatalom) hiányában, a viszonylag egyenlő felek logikai következtetése (racionális egyéni döntési szándék) nem kevesebb, mint az, hogy agresszív magatartással lényegesen növelni lehet a túlélési esélyeket. Hobbes-i értelemben, mint tudjuk, az önfenntartás érdekében akár az agresszivitás is megengedett a hatalommentes állapotban. Döntéseik eredményeként János és István egyaránt 50-50\%-os túlélési esélyt kapnak. Kollektív szinten ez azonban irracionális döntés, hiszen a mindkét részről jövő békés magatartással 80\%-osra emelhetnék túlélési esélyüket. 


\section{TANULMÁNY}

Az egyéni racionális döntéseknek azért is vannak irracionális kollektív következményei, mert az emberi szenvedélyeket kordában tartó hatalom hiányában a természetes ember bírvágyát, illetve a kollektívára (is) ható döntéseit nem az ésszerűség, hanem az egyéni önzés dominálja, ezért követi a természetes ember kizárólag a saját előnyét szolgáló ,játékszabályokat”.

Bizonyos értelemben az érzelmek és az ésszerűség összjátéka olvasható ki Jean Hampton írásából is (Hampton 1986: 58-64), aki egyfelől Hobbes meggyőző erejü racionális érveit követve ad ésszerű magyarázatot a totális háború elkerülhetetlenségére, másfelől David Gauthier gondolatai nyomán (Gauthier 1979) azt vallja, hogy a háborút nem a racionalitás, hanem az emberi szenvedélyek okozzák (Hampton 1986: 63). Részben ezzel magyarázható az is, hogy a természeti állapot embere nem engedelmeskedik a békét eredményező, megváltoztathatatlan és örök érvényű erkölcsszabályoknak, ugyanis szenvedélyei fölülírják a természeti törvényeknek való engedelmességi törekvéseit (Hampton 1986: 64). Érzelmi törekvései viszont lehetetlenné teszik, hogy a szabályok mentén kövesse, és valóban megvalósítsa önfenntartását.

Ahogy Kevevári is összegzi, a háborús állapot elkerülhetetlen, és ennek oka tehát az emberi természet, a szűkös javak és a közhatalom hiányának együttes hatásában keresendő (Kevevári 2019: 1). Ne feledjük azonban, hangsúlyozza Hobbes, mégis van kiút. Az ösztönök, érzelmek, indulatok, illetve az ésszerűség és értelem egyfajta kombinációja közbelép „az utolsó pillanatban” azért, hogy véget vessen az áldatlan állapotnak, amelybe természete révén került az ember. A helyzet tehát nem végzetes, ugyanis ez az állapot „részben érzelmeinken, részben értelmünkön alapuló lehetőséget is nyújtja nekünk, hogy kikerüljünk belőle" (Hobbes 2001: 158). Érzelmei és végtelen önzése önmagukban elkerülhetetlen háborúba taszítaná az embert, halálfélelme hatására és Istentől kapott értelme révén azonban „időben” ráeszmél arra, hogy a béke előnyös alapelveinek követésével (a szuverén hatalom létrehozásával) kordában lehet tartani a szenvedélyeket, el lehet kerülni az önpusztítást, és meg lehet teremteni a viszonylagos békét jelentő rendet.

\section{Összegzés}

Annak ellenére, hogy már többször elhangzott a tanulmányban, a záró részben mégis összegzem tömören a természeti helyzeten nyugvó Hobbes-i elmélet lényegi aspektusait. A kényelmes élethez szükséges dolgok iránti vágya és az a remény, hogy a szükséges javak elérhetők munkával (vagy akár cselszövéssel), olyan érzelmi kategóriák, amelyek önfenntartási ösztöne ellenére egy állandósult háború állapotába sodorják az embert. Helyzete azért nem végzetes, mert halálfélelmétől indíttatva, Istentől kapott értelme révén az ember rájön a katasztrófából való kijutás lehetőségére. 


\section{TANULMÁNY}

A kihívó feladatot azonban a békés és biztonságos együttélés megteremtésének mikéntje képezi, hiszen a természeti törvények ismerete önmagában nem fogja a primitív ösztönöket és a kiszámíthatatlan hajlamokat megfékezett vágyakká, korlátok közé szorított indulatokká finomítani. Ezért mentőövként szolgál a természeti ember számára az a felismerés, hogy élete megőrzéséhez egy külső tényezőre (szuverén hatalom) van szükség, amely képes kötelezővé tenni a békét jelentő normatív szabályokat. A Hobbes által felépített logikai láncreakcióban az eredeti helyzet voltaképpen a hatalom és a „törvény hitelét legitimáló fikció”.

Hobbes vállalkozása sikeresnek bizonyul, hiszen a Leviatán gondos olvasása azt a benyomást kelti, hogy komplexitása és belső ellentmondásai ellenére a természeti állapot megfelelő logikai alapot nyújt az állam létrejötte, a szuverén hatalom léte, a polgári állapot szükségszerűségének bizonyítására. Kérdés persze, hogy a fentebb bemutatott kérdések mellett milyen más tényezők és/vagy szempontok nehezít(het)ik tovább az olvasó és az elemző dolgát. Amint a bevezetőben is említettem (1. jegyzet), a Hobbes-i természeti állapot további négy - dilemmás - kérdésének megválaszolására egy következő tanulmányban kerül sor.

\section{Irodalom}

Austin, J. L. (1990): Tetten ért szavak. Budapest, Akadémiai Kiadó.

Balogh L. L. (2010): „A leviatán autonómiája”. Magyar Filozófiai Szemle 54(2): 101.

Bobbio, N. (1993): Thomas Hobbes and the Natural Law Tradition. Chicago - London, University of Chicago Press.

Curles, E. (ed.) (1994): Thomas Hobbes, Leviathan with Selected Variants from the Latin Edition of 1688. Indianapolis - Cambridge.

Fish, S. (1980): Is There a Text in this Class? The Authority of Interpretive Communities. Cambridge, Mass., Harvard University Press.

Gauthier D. P. (1979): The Logic of Leviathan. Oxford, Clarendon Press.

Hampton, J. (1986): Hobbes and the Social Contract Tradition. Cambridge, Cambridge University Press.

Hobbes, Th. (1994) [1640]: The Elements of Law. Oxford, Oxford University Press.

Hobbes Th. [1642]: De Cive Public Library UK. http://www.public-library.uk/ ebooks/27/57.pdf (utolsó letöltés ideje: 2020. 08. 30.)

Hobbes, Th. (1998) [1651]: On the Citizen. Cambridge, Cambridge University Press.

Hobbes, Th. (2001) [1651]: Leviatán. Kolozsvár, Polis Könyvkiadó.

Horváth B. (2001) [1943]: Angol jogelmélet. Budapest, Pallas Stúdió - Attraktor. 


\section{TANULMÁNY}

Kevevári I. (2019): „A fenavad, aki uralkodik felettünk: a szuverenitás fogalmának dekonstrukciója Jackes Derrida kései előadásaiban”. Iustum Aequum Salutare XV (1), 53-70. http://ias.jak.ppke.hu/hir/ias/20191sz/03_Kevevari_IAS_2019_1.pdf (utolsó letöltés ideje: 2020. 07. 28.)

Laslett, P. (1967): „Social Contract”. In: Edwards, P. (ed.): Encyclopedia of Philosophy, 7.

Ludassy M. (1999): Elhiszem, mert ésszerü. Budapest, Osiris Kiadó.

Ludassy M. (2007): „Halandó istenség és mesterséges örökkévalóság. A „Leviatán” metaforái”. Holmi, 2007/1., 45-53. http://epa.oszk.hu/01000/01050/00037/ pdf/holmi_2007_01_045-053.pdf (utolsó letöltés ideje: 2020.10.15)

McCormick, P. (1976): „Social Contract: Interpretation and Misinterpretation”. Canadian Journal of Political Science, 9(1): 63-76.

Miller, B. (1988): „Hobbes: On Religion”. Political Theory, Sage Publications, Inc., 16(3): 400-425.

Moloney, P. (1997): „Leaving the Garden of Eden: Linguistic and Political Authority in Thomas Hobbes. History of Political Thought, 18(2).

Oakeshott, M. (1975): Hobbes on Civil Association. Oxford, Basil Blackwell.

Orthmayr Imre (2013): „Szerződéselmélet, aranykorelmélet és társadalomtudomány". Magyar Filozófiai Szemle, 57(1): 9-37.

http://real.mtak.hu/34260/1/Orthmayr_Imre_Szerzodeselmelet_aranykorelmelet_es_tarsadalomtudomany_u.pdf (utolsó letöltés ideje: 2020.07.11.)

Rauch, L. (1991): „Secular Fall and Redemption in Hobbes’ Leviathan”. In: Shaw, W. P. (ed.): Praise Disjoined: Changing Patterns of Salvation in 17 $17^{\text {th }}$ Century English Literature. New York, Peter Lang.

Sharpe, K. (2000): Reading Revolutions - The Politics of Reading in Early Modern England. New Haven - London, Yale University.

Skinner, Q. (1997): „Jelentés és megértés az eszmetörténetben”. In Horkay Hörcher F. (szerk.): A koramodern politikai eszmetörténet cambridge-i látképe. Tanulmány Kiadó, Pécs.

Sorell, T. (1986): Hobbes. London, Routledge \& Kegan Paul.

Spinoza, B. (1997) [1677]): Etika. (Ford. Szemere Samu, átdolgozta Boros Gábor), Budapest, Osiris Kiadó.

Stauffer, D. (2010): „Of Religion” in Hobbes's Leviathan”. The Journal of Politics, The University of Chicago Press, 72(3): 868-879.

Stephen, L. (2013) [1904]: Hobbes. London, Hard Press Publishing. 


\section{TANULMÁNY}

Thorton, H. (2002): „Cain, Abel and Thomas Hobbes”. History of Political Thought, 23(4), winter 2002. https://www.jstor.org/stable/26219895?seq=1 (utolsó letöltés ideje: 2020. 07.22.)

Thorton, H. (2005): State of Nature or Eden?: Thomas Hobbes and His Contemporaries on the Natural Condition of Human Beings. Boydell \& Brewer, University of Rochester Press.

Tóth J. (2020): Társadalomfilozófia. Szegedi Tudományegyetem http://eta.bibl.u-szeged.hu/2496/ (utolsó letöltés ideje: 2020. 08. 20.)

Warrender, H. (1957): The Political Philosophy of Hobbes. Oxford, Clarendon Press.

Wolin, Sh. S. (1960): Politics and Vision - Continuity and Innovation in Western Political Thought. Boston, Little, Brown \& Co. Inc. 